\title{
Tendency and Causes Analysis of Marine Water Quality of Jinzhou Bay
}

\author{
Zhao Junjie ${ }^{1}$, Shou Youping ${ }^{1, *}$, Bai Jing $^{1}$ and Wang Ning ${ }^{1}$ \\ ${ }^{1}$ Laboratory of Waterway Environmental Protection Technology, Tianjin Research Institute for Water Transport Engineering,Tianjin \\ 300456, China
}

\begin{abstract}
Based on the two monitoring data of Jinzhou Bay in July 2008, September 2013 and September 2016, this article analysis the temporal trends of marine water quality of Jinzhou Bay. The average concentration of COD, inorganic nitrogen and phosphate is between $1.09 \mathrm{mg} / \mathrm{L} \sim 1.45 \mathrm{mg} / \mathrm{L}$, $0.42 \mathrm{mg} / \mathrm{L} \sim 0.711 \mathrm{mg} / \mathrm{L}$ and $0.006 \mathrm{mg} / \mathrm{L} \sim 0.03 \mathrm{mg} / \mathrm{L}$, respectively. The concentration of inorganic nitrogen showed a downward trend while the concentration of phosphate showed an increased trend. Meanwhile, the concentration of COD had no significant change. Results showed that the inorganic nitrogen concentration and phosphate concentration have good correlation with eutrophication index and Eutrophication parameters (E) showing a clear upward trend. The emission of active phosphates and inorganic nitrogen from land-based pollutants are the main cause of this phenomenon.
\end{abstract}

\section{Preface}

In recent years, with the exploit of China's coastal zones and the development of the main marine economy, pollutants discharge into the sea which resulted in the environmental pressures increased in coastal waters ${ }^{[1]}$. The Jinzhou Bay is the western half of Liaodong Bay which has 105.2 kilometers coastline located at the bottom of the nearly closed Bohai Sea. It has small tidal range and weak seawater exchange capacity ${ }^{[2]}$. Red tide, eutrophication, heavy metals and oil pollution Frequent occurred in Jinzhou Bay ${ }^{[3]}$. The problem of coastal waters pollution has become a bottleneck for sustainable development ${ }^{[4]}$. With the development of jinzhou's industry and the expansion of mariculture, especially the continuous development and construction of Jinzhou Port in recent years, a large amount of inorganic nitrogen has been discharged into the sea area, resulting in the pollution of inorganic nitrogen in the sea area ${ }^{[5]}$. As a major nutrient, phosphate mainly comes from the emission of human activities, which has been recognized [6]. In view of the harm that eutrophication brings to water environment, water eutrophication has become one of the major environmental problems of global concern [7].

Jinzhou Port was constructed from 2010 to 2014. During the construction of Jinzhou Port, the sediment was dredged and the land-based pollutants were discharged intensively. Due to its special geographical position, the water exchange and material transport in the Bohai Sea are significantly different from those in other open seas ${ }^{[8 \sim 9]}$.

Therefore, the study of the tendency and Causes analysis of water quality in Jinzhou Bay is very important to controlling coastal pollution and improving environmental quality.

\section{MATERIALS AND METHODS}

\subsection{Monitoring data}

This paper collected three monitoring data of Jinzhou Bay in July 2008 and September 2016, which were monitored by Jinzhou Environmental Monitoring Center Station and Fujian Zhonghai Testing Technology Co., Ltd., separately. These data represent the background value and current status of Marine Water Quality of Jinzhou Bay, separately. This paper by comparison of Marine Water Quality of Jinzhou Bay to analysis the trends and causes of marine water quality.

\subsection{Research methods}

Technical Regulations for Assessment of Seawater Quality Status (Trial) (2015.10) introduced the method for calculation of eutrophication index(E). The specific calculation formula is as follows:

$E=\left(C_{\mathrm{COD}} \times C_{\mathrm{DIN}} \times C_{\mathrm{DIP}} \times 10^{6}\right) / 4500$

$E-$ Eutrophication index.

$C_{\mathrm{COD}}$ the concentration of Chemical oxygen demand, $\mathrm{mg} / \mathrm{L}$.

$\mathrm{C}_{\mathrm{DIN}}$ - the concentration of Inorganic nitrogen(IN$\mathrm{N})$, which is the sum of nitrite-nitrogen $\left(\mathrm{NO}_{2}-\mathrm{N}\right)$, nitratenitrogen $\left(\mathrm{NO}_{3}-\mathrm{N}\right)$ and ammonia-nitrogen $\left(\mathrm{NH}_{4}-\mathrm{N}\right), \mathrm{mg} / \mathrm{L}$.

$C_{\text {DIP }}$ the concentration of Active phosphate, $\mathrm{mg} / \mathrm{L}$.

\footnotetext{
* Corresponding author: syp851228@126.com
} 
Partition table of Eutrophication index is listed in Table 1.

Table 1. Partition table of Eutrophication index (E).

\begin{tabular}{|c|c|}
\hline Eutrophication level & Eutrophication index(E) \\
\hline Light eutrophication & $1 \leq \mathrm{E} \leq 3$ \\
\hline Moderate eutrophication & $3<\mathrm{E} \leq 9$ \\
\hline Severe eutrophication & $1 \mathrm{E}>3$ \\
\hline
\end{tabular}

\section{RESULTS AND DISCUSSION}

\subsection{Inorganic salt concentration}

The concentration of inorganic salts in surface water at high tide and ebb tide in 2008.7 and 2016.9 are listed in Table 2. The trend of the COD, inorganic nitrogen and phosphate concentration change at high tide and ebb tide in 2008.7 and 2016.9 are showed in Figure 1, Figure 2 and Figure 3. The average concentration of COD, inorganic nitrogen and phosphate are between $1.09 \mathrm{mg} / \mathrm{L}$ $\sim 1.45 \mathrm{mg} / \mathrm{L}, 0.42 \mathrm{mg} / \mathrm{L} \sim 0.711 \mathrm{mg} / \mathrm{L}$ and $0.006 \mathrm{mg} / \mathrm{L}$ $\sim 0.03 \mathrm{mg} / \mathrm{L}$, respectively.

From Table 2 and Figure 1, we can see that the concentration of COD had no significant changes. The above phenomenon may be due to the positive effect of the Implementation of the Bohai Sea Blue Sea Action Plan on organic pollution in the Bohai Sea water, which reduced the contribution rate of Marine runoff to organic pollutants in the sea from $66 \%$ in 1995 to $44 \%$ in $2005^{[10]}$. The temporal and spatial paging characteristics of COD may be weakened.

For the interannual variability, the concentration of inorganic nitrogen showed a downward trend. At the same time, the concentration of COD at high tide is greater than that at low tide. The results show that inorganic nitrogen is seriously affected by terrestrial emissions, terrestrial pollution has been effectively controlled in recent years, and inorganic nitrogen in Marine water quality presents an obvious trend of decline. Due to the Environmental Quality Public in China's Coastal Waters from 2006 to 2017, inorganic nitrogen is the main pollution factor, and nitrogen is one of the pollutants with the greatest influence.

From Table 2 and Figure 1, we can see that the concentration of phosphate showed an increased trend. Due to the discharge of human pollutants, the trend of phosphorus pollution in seawater is increasing.

Table 2. The concentration of inorganic salts in surface water at high tide and ebb tide in 2008.7 and 2016.9.

\begin{tabular}{|c|c|c|c|c|c|}
\hline \multirow{2}{*}{$\begin{array}{c}\text { Survey } \\
\text { Time }\end{array}$} & \multirow{2}{*}{ Value } & \multicolumn{3}{|c|}{ concentration $(\mathrm{mg} / \mathrm{L})$} & \multirow{2}{*}{ E } \\
\hline & & COD & IN & $\mathrm{PO}_{4}^{3-}$ & \\
\hline \multirow{3}{*}{$\begin{array}{l}\text { High } \\
\text { tide in } \\
2008.7\end{array}$} & $\begin{array}{l}\text { Minimum } \\
\text { value }\end{array}$ & 1.04 & 0.434 & 0.004 & 0.60 \\
\hline & $\begin{array}{l}\text { Maximum } \\
\text { value }\end{array}$ & 1.6 & 1.042 & 0.02 & 4.86 \\
\hline & $\begin{array}{l}\text { Mean } \\
\text { value }\end{array}$ & 1.23 & 0.711 & 0.011 & 2.30 \\
\hline $\begin{array}{l}\text { Ebb } \\
\text { tide in }\end{array}$ & $\begin{array}{l}\text { Minimum } \\
\text { value }\end{array}$ & 1.06 & 0.463 & 0.004 & 0.54 \\
\hline
\end{tabular}

\begin{tabular}{|c|c|c|c|c|c|}
\hline \multirow[t]{2}{*}{2008.7} & $\begin{array}{l}\text { Maximum } \\
\text { value }\end{array}$ & 1.72 & 1.041 & 0.008 & 2.29 \\
\hline & $\begin{array}{l}\text { Mean } \\
\text { value }\end{array}$ & 1.3 & 0.654 & 0.006 & 1.16 \\
\hline \multirow{3}{*}{$\begin{array}{c}\text { High } \\
\text { tide in } \\
2016.9\end{array}$} & $\begin{array}{l}\text { Minimum } \\
\text { value }\end{array}$ & 0.73 & 0.36 & 0.02 & 1.40 \\
\hline & $\begin{array}{l}\text { Maximum } \\
\text { value }\end{array}$ & 1.69 & 0.62 & 0.03 & 6.21 \\
\hline & $\begin{array}{l}\text { Mean } \\
\text { value }\end{array}$ & 1.45 & 0.47 & 0.02 & 3.49 \\
\hline \multirow{3}{*}{$\begin{array}{c}\text { Ebb } \\
\text { tide in } \\
2016.9\end{array}$} & $\begin{array}{l}\text { Minimum } \\
\text { value }\end{array}$ & 0.41 & 0.26 & 0.02 & 0.87 \\
\hline & $\begin{array}{l}\text { Maximum } \\
\text { value }\end{array}$ & 1.56 & 0.56 & 0.04 & 6.13 \\
\hline & $\begin{array}{l}\text { Mean } \\
\text { value }\end{array}$ & 1.09 & 0.42 & 0.03 & 2.89 \\
\hline
\end{tabular}

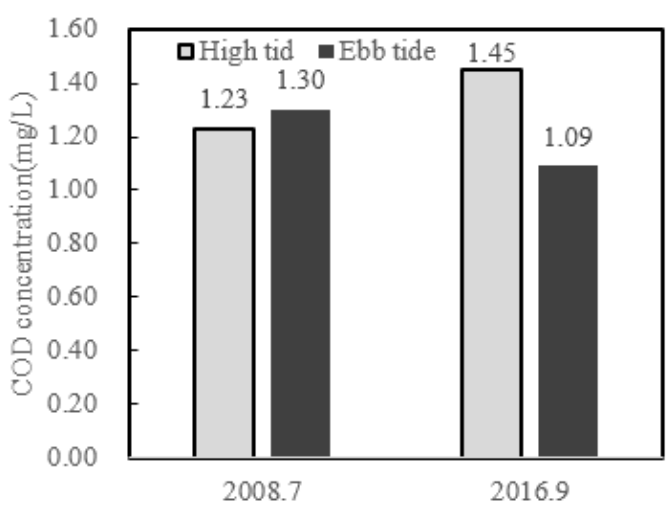

Figure 1. The trend of the COD concentration change at high tide and ebb tide in 2008.7 and 2016.9.

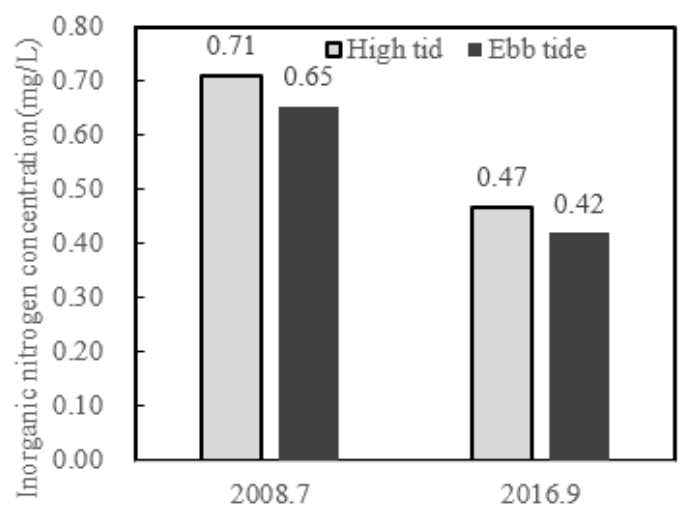

Figure 2. The trend of the inorganic nitrogen concentration change at high tide and ebb tide in 2008.7 and 2016.9.

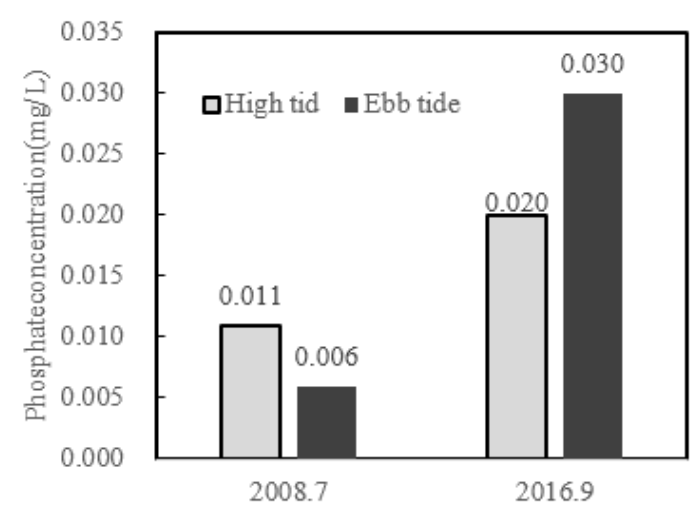

Figure 3. The trend of the phosphate concentration change at high tide and ebb tide in 2008.7 and 2016.9. 


\subsection{Eutrophication index}

Eutrophication index(E) are listed in Table 2 which increased in these years. The average Eutrophication index $(\mathrm{E})$ is 2.30 and 1.16 at high tide and ebb tide in July 2008. While the average Eutrophication index (E) is 3.49 and 2.89 at high tide and ebb tide in September 2016.

The trend of the eutrophication index (E) change at high tide and ebb tide in 2008.7 and 2016.9 are showed in Figure 4. It can be seen from the figure that the period of eutrophication index in high tide is greater than that in ebb tide. A large number of organic pollutants and nutrient salts are discharged into the coastal waters, in addition, water exchange is not smooth due to the semiclosed nature of Bohai Bay, resulting in eutrophication of water bodies becoming a major environmental problem in this sea area ${ }^{[11]}$. The high degree of eutrophication of water quality during high tide also proves that the eutrophication of waters in Jinzhou sea area is mainly affected by land discharge.

In order to better analyze the causes of eutrophication of marine water, correlation analysis between eutrophication index(E) and COD, inorganic nitrogen, phosphate concentration were exhaustive analyzed. The trend of the eutrophication index(E) and its impact factors is shown in Figure 5. It can be seen from the figure that COD concentration is not correlated with Eutrophication index (E). This result tells us that the eutrophication of Jinzhou sea water body is less affected by COD.

Figure 5 showed that the inorganic nitrogen concentration and phosphate concentration have good correlation with eutrophication index (E). The emission of active phosphates and inorganic nitrogen from landbased pollutants is the main cause of this phenomenon.

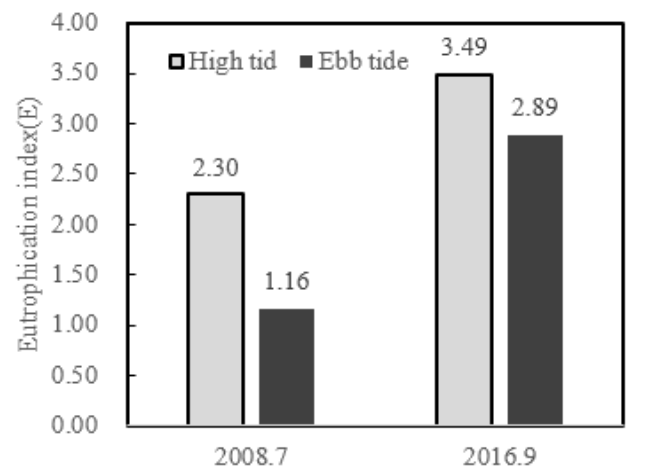

Figure 4. The trend of the eutrophication index(E) change at high tide and ebb tide in 2008.7 and 2016.9.
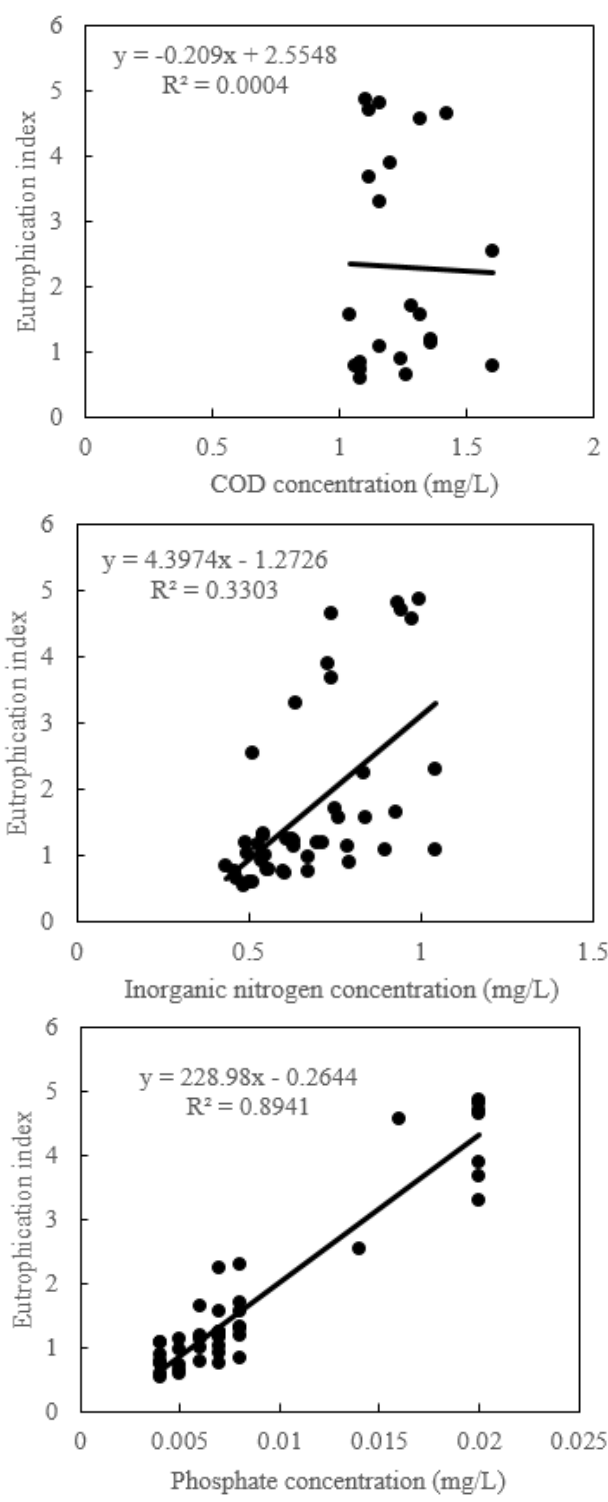

Figure 5. Correlation analysis between eutrophication index(E) and COD, inorganic nitrogen, phosphate concentration

\section{CONCLUSION}

The average concentration of COD, inorganic nitrogen and phosphate are between $1.09 \mathrm{mg} / \mathrm{L} \sim 1.45 \mathrm{mg} / \mathrm{L}$, $0.42 \mathrm{mg} / \mathrm{L} \sim 0.711 \mathrm{mg} / \mathrm{L}$ and $0.006 \mathrm{mg} / \mathrm{L} \sim 0.03 \mathrm{mg} / \mathrm{L}$, respectively.

For the interannual variability, the concentration of inorganic nitrogen showed a downward trend, the concentration of phosphate showed an increased trend, the concentration of COD had no significant changes.

COD concentration is not correlated with Eutrophication index (E). Inorganic nitrogen concentration and phosphate concentration have good correlation with eutrophication index $(\mathrm{E})$.

Phosphate concentration and Eutrophication parameters (E) show an upward trend at the same time tell us the emission of active phosphates from land-based pollutants is the main cause of this phenomenon. 


\section{ACKNOWLEDGMENTS}

This paper is one of the phased achievements of the National Nonprofit Institute Research Grants of Tianjin Research Institute for Study on integrated Remediation technology of Immobilized microorganisms in Polluted sea water (No. TKS190408).

\section{REFERENCES}

1. Chen B.1., He X.R., Zhan W.H. (2006) Study on Tottal Quantity Control for Lianyungang Harbor Area. Periodical of Ocean University of China:36 (03) :447-450.

2. Song 1., Wang N.B., Song Y.G. (2013). The Ecosystem Health Assessment of Jinzhou Bay. Environmental Monitoring in China. 29:15-20.

3. Chen W.J., Zhou J.F., LI Y.C.(2010) Tendency and Causes Analysis of Marine Water Quality of Daya Bay. Environmental Science \& Technology,3(12):28-32.

4. Dang E., Long C., Zhang N.(2020) Study on water quality and eutrophication level in the coastal area of Dapeng Bay. Journal of Environmental Engineering Technology,10(4):623-630.

5. Dang E., Tang J.Y., Zhou L.N. (2019). Water quality assessment and eutrophication analysis in coastal waters of Pearl River estuary. Journal of Dalian Fisheries University,34(4):580-587.

6. Liu Y.H., Yang X.L., Jin Y.(2011) Distribution and inter-annual variation of nutrients in Laizhou Bay. Marine Fisheries Research,32(4):1-5.

7. Xu N. N., Qiu Y., Yao Y.M.(2015) Ecological Environment Changes in Zhoushan Coastal Waters from 2002 to 2011. Journal of Anhui Agricultural Sciences, 3:292-296.

8. Sui Q., Xia B., Xie H.B.(2016) Study on Temporal and Spatial Variation of Nutrients and Evaluation on Eutrophication in the Seawater of the Bohai Sea in Winter and Spring of 2014. Progress In Fishery Sciences,3:10-15.

9. Wang X., Liu Y.F., Guo W. (2019). Evaluation of environmental quality and change trend in Sansha Bay mariculture area in recent ten years. Journal of Fisheries Research,41(6):519-525.

10. Liu J(2006). Study on the main pollutant fluxex into the Bohai. Ocean University of China.

11. Tang D.L., Kawamura H. (2006) Satellite evidence of harmful algal blooms and related oceanographic features in the Bohai Sea during autumn 1998. Advances in Space Research, 37(4):681-689. 